\title{
Analysis of parallelism tolerances and its influence on Bearing tension tests on structural composite performance according to ASTM D5961
}

\section{Análise de tolerâncias de paralelismo e sua influência nos testes de tensão de Bearing no desempenho de compósitos estruturais de acordo com ASTM D5961}

Luana Pereira Dalla Mariga', Everton Sérgio Ribeiro da Silva², Felipe Pinto Pêcego ${ }^{3}$, William Marcos Muniz Menezes ${ }^{1}$,

Rita de Cássia Mendonça Sales ${ }^{1}$

\begin{abstract}
This article has the purpose of verifying the parallelism geometrical tolerance application on the response of single lap composite joints, riveted with two fasteners, for bearing test in tension, according to ASTM D5961 - procedure B, using for this finite element analysis software and short bibliographic review. It was also studied a more affordable for manufacturing alternative, with $1 \mathrm{~mm}$ of parallelism tolerance. Furthermore, it was mentioned variables on the composite joints obtainment which are more critical for its structural performance, as hole/fastener gap, pitch, fiber/matrix mating, lay-up and edge distance, for example, and, in conclusion, raised as a hypothesis, that an error in the order of magnitude of tenth millimeter of parallelism would not affect the bearing primary failure in a significant manner.
\end{abstract}

Keywords: Parallelism tolerance, Bearing test in tension, Structural performance.

\section{RESUMO}

O presente trabalho estuda a influência da aplicação da tolerância de paralelismo no desempenho estrutural de juntas compósitas sujeitas a cisalhamento simples, unidas com dois prendedores, para execução de ensaio de bearing em tração, conforme procedimento B da norma ASTM D5961, a partir de simulação em software de elementos finitos e breve revisão bibliográfica. Foi estudada também alternativa mais viável para manufatura, com tolerância de paralelismo de $1 \mathrm{~mm}$. Por fim, foram citadas variáveis inerentes ao processo de obtenção de juntas compósitas mais críticas ao desempenho estrutural, como folga furo/pino, passo, acoplamento fibra/matriz, empilhamento e distância de borda, por exemplo, e levantado como hipótese que um erro na ordem de décimos de milímetro de paralelismo não afetaria de forma significativa o modo de falha primário por bearing.

Palavras-chave: Tolerância de paralelismo, Ensaio de bearing em tração, Desempenho estrutural.

\footnotetext{
${ }^{1}$ Faculdade de Tecnologia de São José dos Campos - FATEC Professor Jessen Vidal - São José dos Campos/SP - Brazil. ¿Universidade Paulista - UNIP - Mechanical Engineering Department - São José dos Campos/SP - Brazil.

3Universidade Estadual Paulista "Júlio Mesquita Filho" - Mechanical Engineering Department - Guaratinguetá/SP - Brazil.

Correspondence author: Luana Pereira Dalla Mariga | Faculdade de Tecnologia de São José dos Campos - FATEC Professor Jessen Vidal | Av. Cesare

Mansueto Giulio Lattes, 1350 | CEP 12247-014 - São José dos Campos/SP - Brazil | E-mail: luana.mariga@gmail.com

Received: Feb. 16, 2018 | Accepted: Mar. 23, 2018
} 


\section{INTRODUCTION}

Structural joints are one of the biggest challenges in structural design $^{1}$, and therefore, relevant for mechanical tests and stress analysis ${ }^{2}$. Stress concentration occurs on its force transference points and the attachment element and/or the respective joint nearby regions are always pre-deformed ${ }^{3}$. Furthermore, joints are the most common source of repair and failures in aircrafts ${ }^{1}$.

In aircrafts, the most used structural joint is the mechanical attached type ${ }^{1}$. Among them, single lap joints are more significant for bearing effect analyses. Beyond inducing shear loads on the fasteners, in comparison with double lap joints, single lap joints have higher stress concentrations on the holes wall due to the smaller contact area, and induce bending loads on the fastener due to the secondary moment resultant of the joint geometry.

Composite materials failure modes are usually complex processes, occurring in a progressive way and affecting the liability of the manufactured components ${ }^{2}$. The most common composite failure modes are illustrated on Figs. $1^{4}$ and 2 (adapted) ${ }^{5}$.

Among the most influent factors in composite failure modes, load alignment and even stress distribution are the hypothesis related with the critical parallelism tolerance indicated on procedure $\mathrm{B}^{6}$, and therefore studied in this article.

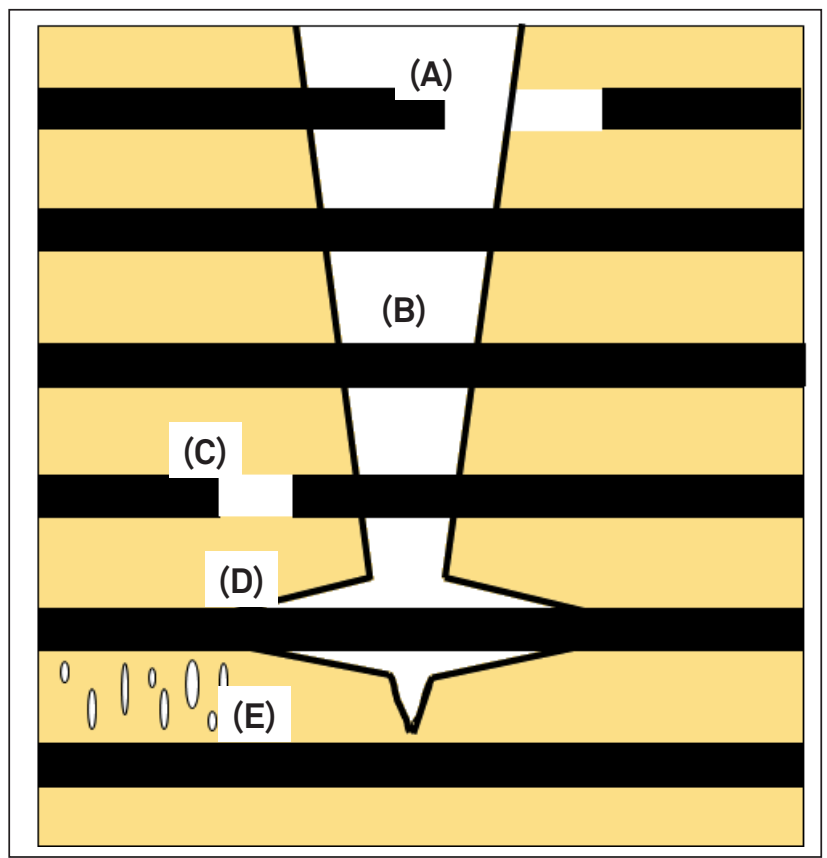

Figure 1: Intra laminates between the laminate layers failure modes: (A) debonding; (B) pull-out; (C) fiber bridging; (D) fiber rupture; (E) matrix damage ${ }^{4}$.

\section{Procedure B - ASTM D5961}

ASTM D5961 standard ${ }^{6}$ covers the guidelines for composite pinned or fastened joints bearing tests, using multi-directional polymer matrix, balanced and symmetric with respect to the test direction, reinforced by high-modulus fibers ${ }^{2}$.

This article studies the influence and necessity of the parallelism tolerance related to datum $\mathrm{A}$, as required on procedure $\mathrm{B}$ (indicated on Fig. 3$)^{6}$, in the composite joint structural performance, considering that the stipulated centesimal tolerance increases manufacturing expenses.

The test specimen consists on single lap composite joint, attached with two fasteners and two doublers bonded to the specimen (indicated by s dimension on Fig. 3), which have the function of guarantee the load direction coincident to the joint interface, in order to avoid a secondary bending moment ${ }^{2}$.

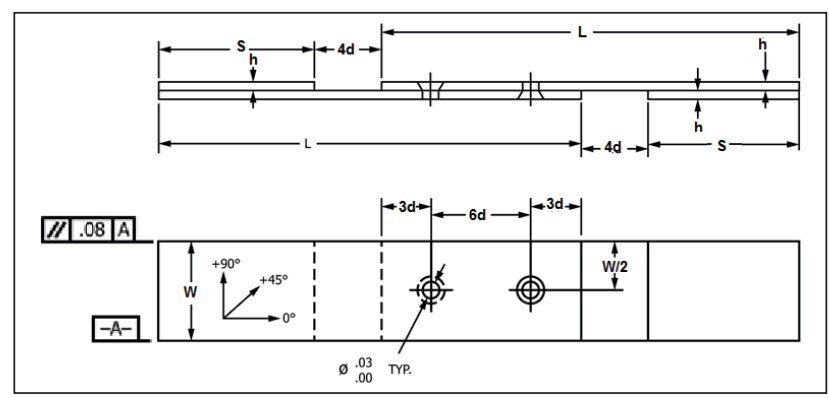

Figure 3: Single-shear, two-piece double-fastener specimen, for bearing test, according to Procedure B of ASTM D5961 standard6.

\section{Bearing}

Bearing is the crushing in the hole wall caused by a pressure induced by the fastener due to an external load ${ }^{2}$, as demonstrated in Fig. $4^{7}$. Figure 5 illustrates typical composite laminate bearing failures ${ }^{8}$.

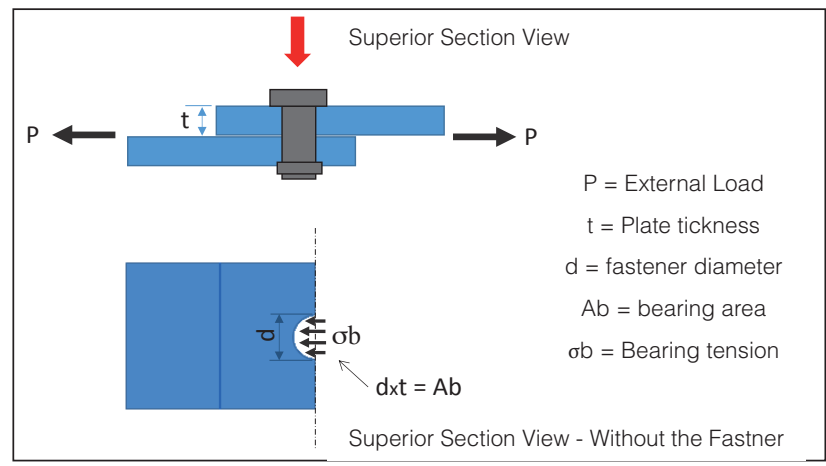

Figure 4: Bearing stress in riveted single lap joint hole wall.

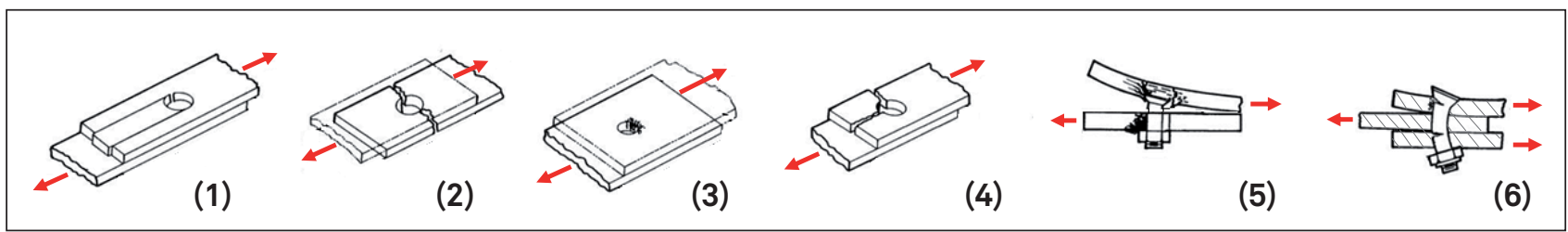

Figure 2: Composite joints failure modes: (1) shear; (2) tension; (3) bearing; (4) tension and shear; (5) fastener pull through and delamination; (6) fastener failure. 


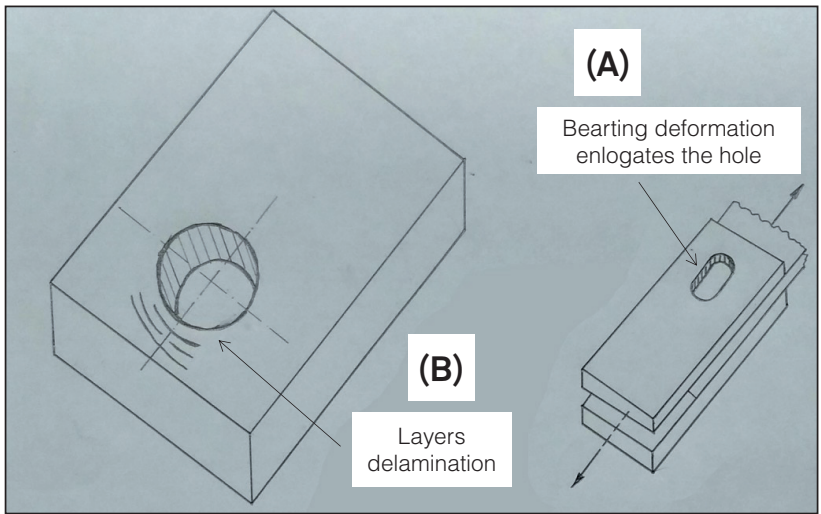

Figure 5: Bearing failures: (A) defect on circular form; (B) delamination.

\section{Load Alignment and By-pass}

The load direction is critical in composite joints due to its heterogeneity, orthotropy and low ductility ${ }^{9}$. Different from isotropic materials, composite material properties change according to the fiber orientation, showing higher stiffness and strength on its parallel direction, when considering unidirectional reinforcements ${ }^{10}$. Furthermore, the secondary moment caused by load application eccentricity overload the fasteners, which can lead to excessively tensioned couplings ${ }^{2}$ and, in joints with gaps between hole and fasteners, rotate the fixer, resulting in uneven load distribution along the test specimen thickness ${ }^{1}$. The higher the bending moment applied on the fastener, the higher the chance of its deformation and also the bearing on the hole wall ${ }^{2}$.

Moreover, a load misalignment can induce to a higher by-pass portion, which is a load deviated to the specimen plates areas in tension stress form, as showed in Fig. 6. Considering Procedure B of ASTM D5961 ${ }^{6}$, the by-pass portion must be lower than $20 \%{ }^{2}$, otherwise it could produce tension and compression failures or shear and tension combined failure, and therefore invalidate the test ${ }^{6}$.

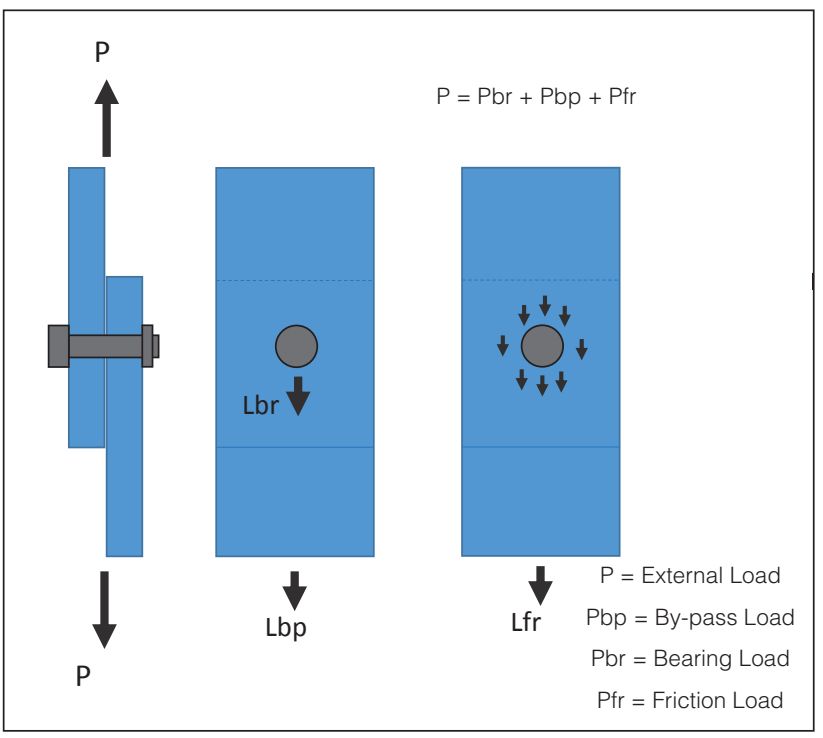

Figure 6: Demonstration of loads that act in a joint ${ }^{2}$.

\section{MATERIALS AND METHODS}

For this study, it was selected an intermediate modulus composite laminate material, pre-impregnated, similar to those used in aeronautical components, consisting in unidirectional high strength carbon fibers in high strength and high toughness epoxy resin matrix ${ }^{11}$ with the elastic properties showed on Table $1^{12}$, which were input for the simulation on Finite Element Analysis software:

Table 1: Material elastic properties ${ }^{12}$.

\begin{tabular}{|c|c|c|c|}
\hline Property & $\begin{array}{c}\text { Value } \\
(\mathrm{GPa})\end{array}$ & Property & $\begin{array}{c}\text { Value } \\
(\mathrm{GPa})\end{array}$ \\
\hline $\begin{array}{c}\text { Longitudinal Elastic } \\
\text { Modulus }\left(\mathrm{E}_{1}\right)\end{array}$ & 147 & $\begin{array}{c}\text { Longitudinal tensile and } \\
\text { compressive strength } \\
(\text { Xt and Xc, Dir } 1)\end{array}$ & 2.86 \\
\hline $\begin{array}{c}\text { Transverse Elastic } \\
\text { Moduli }\left(\mathrm{E}_{2}\right)\end{array}$ & 7.58 & $\begin{array}{c}\text { Transverse tensile and } \\
\text { compressive strenght } \\
\text { (Yt and Yc, Dir } 2)\end{array}$ & 1.55 \\
\hline $\begin{array}{c}\text { In-plane shear } \\
\text { modulus }\left(\mathrm{G}_{12}\right) \text { and } \\
\text { Interlaminar shear } \\
\text { modulus }\left(\mathrm{G}_{13}\right)\end{array}$ & 3.96 & $\begin{array}{c}\text { In-plane Poisson's } \\
\text { ratio }\left(v_{12}\right)\end{array}$ & 0.33 \\
\hline $\begin{array}{c}\text { Interlaminar Shear } \\
\text { Modulus }\left(\mathrm{G}_{23}\right)\end{array}$ & 3.0 & Shear strength $(\mathrm{S})$ & 0.104 \\
\hline
\end{tabular}

The test specimen geometry followed the procedure $B$ requirements ${ }^{6}$, according to Table 2 , with two $1 / 4$ " fasteners, simulated by two rigid bodies named RBE2 in Nastran $\odot$ software.

Table 2: Test Specimen Geometry and Lay-up parameters.

\begin{tabular}{|c|c|}
\hline Parameter & Values \\
\hline Hole diameter $\varnothing$ & 6.337 to $6.387 \mathrm{~mm}$ \\
\hline Thickness $\mathrm{h}$ & $3.07 \mathrm{~mm}$ (16 layers) \\
\hline Length L & $210 \mathrm{~mm}$ \\
\hline Width W $(6 \mathrm{~d})$ & $38.1 \mathrm{~mm}$ \\
\hline Edge Distance W/2 & $19.05 \mathrm{~mm}$ \\
\hline Lay-up (quasi-isotropic) & {$[45 / 0 /-45 / 90] 2 \mathrm{~s}$} \\
\hline
\end{tabular}

Concerning to the method, it was used Finite Element Analysis in Nastran $\odot$ and Femap $\odot$ softwares, with Maximum Deformation criteria, $1 \mathrm{~mm}$ elements, mesh density of 1 element per square millimeter, application of $2000 \mathrm{daN}$ load in the joint longitudinal direction. It was also used RBE element distributing the forces evenly in one test Specimen extremity and simulated two boundary conditions, the first one as the baseline required in ASTM D5961 - procedure B6, and the second on with $1 \mathrm{~mm}$ of parallelism error applied (Fig. 7).

Boundary condition 1 simulated the joint attached in the left border and free only for longitudinal displacement in the right border, in which the load was applied. This simulation aimed to be similar to the real condition of the specimens attachment in the tension machine during the test. The boundary condition 2 simulated the joint enclosed in the left border and free in the right border. Table 3 shows a sketch to better comprehension about the geometries and boundary conditions simulated. 


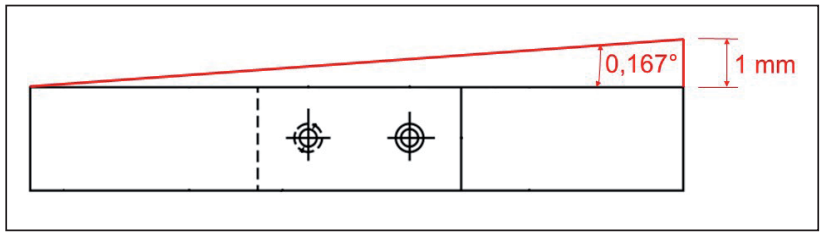

Figure 7: Parallelism error sketch, without scale.

Table 3: Boundary conditions and geometries simulated.

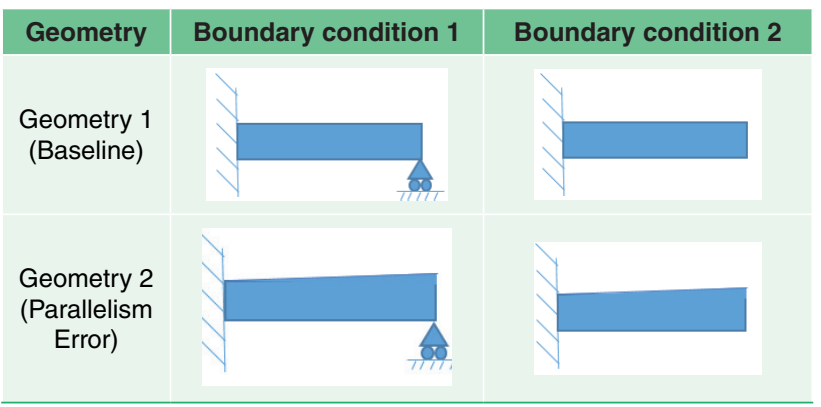

\section{RESULTS AND DISCUSSIONS}

The boundary condition 1 resulted in $-0.014 \mathrm{~mm}$ of translation difference between geometries 1 and 2 (Figs. 8 and 9), showing that the error condition had lower strain due to its area increase. This condition would be different if the parallelism error was applied in the opposite direction (inwards to the test specimen),

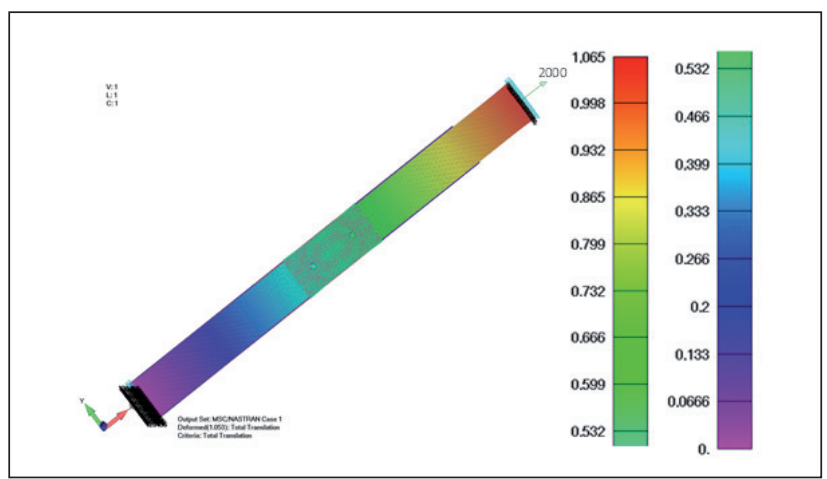

Figure 8: Boundary condition 1, geometry 1 (according to ASTM D5961 - procedure B), strain result (values in $\mathrm{mm}$ ).

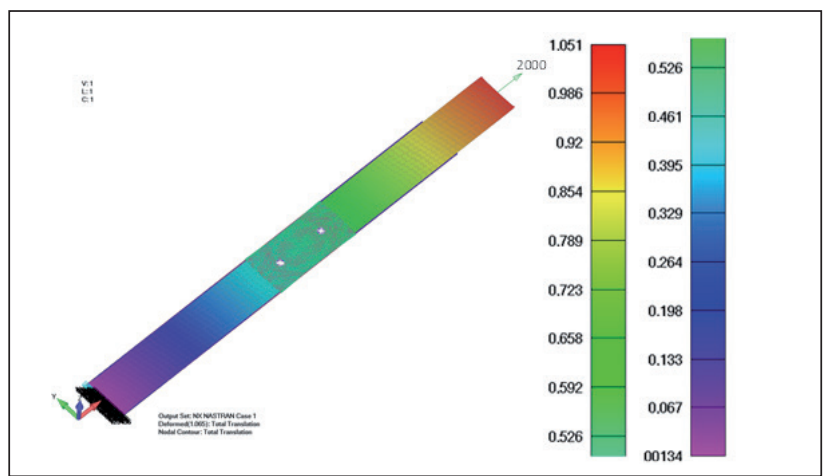

Figure 9: Strain result in geometry 2 (with parallelism error applied), boundary condition 1 (values in $\mathrm{mm}$ ). reducing the joint cross-section area instead of increasing it. The dark blue shadow around the test specimens indicates their initial forms as a reference, in scale to better visualization.

Theoretically it might occur higher by-pass portion in geometry 2 due to the wedge shape cross-section area increase, but it was not estimated the percentage of this change. Anyhow, even applying $1 \mathrm{~mm}$ of parallelism and area error, the difference is too small to change or mask the bearing primary failure mode, although it could change other parameters as force and strain, once it changes the area and load direction.

The second part of the simulation checked the fail index (dimensionless values), which is a software analysis that represents the ratio between the material strength allowable and the load applied, resulting in dimensionless values. The result was that, in any boundary conditions, the joint has not failed (error smaller than 1), showing a difference of only 0.001 between baseline and with error applied geometries, as illustrated in Figs. 10 and 11.

The results were consonant with the expected for the test, as showed by the small light blue area in the attached edges of the test specimen, indicating slow stress increase and higher fail index in the holes that are closer to the load application points and reaction, as illustrated in Fig. 12. This happens because the deformation is gradually higher the closest the fastener is from the point on load application ${ }^{13}$.

At last, it was simulated Geometry 2 in the second boundary condition (joint enclosed in the left border and free in all degrees in the right border), as showed in Fig. 13.

The result in translation difference was $0.506 \mathrm{~mm}$, higher than in boundary condition 1 . This translation difference is assigned to the load misalignment, resulting in a secondary bending moment, and demonstrates that a parallelism error would

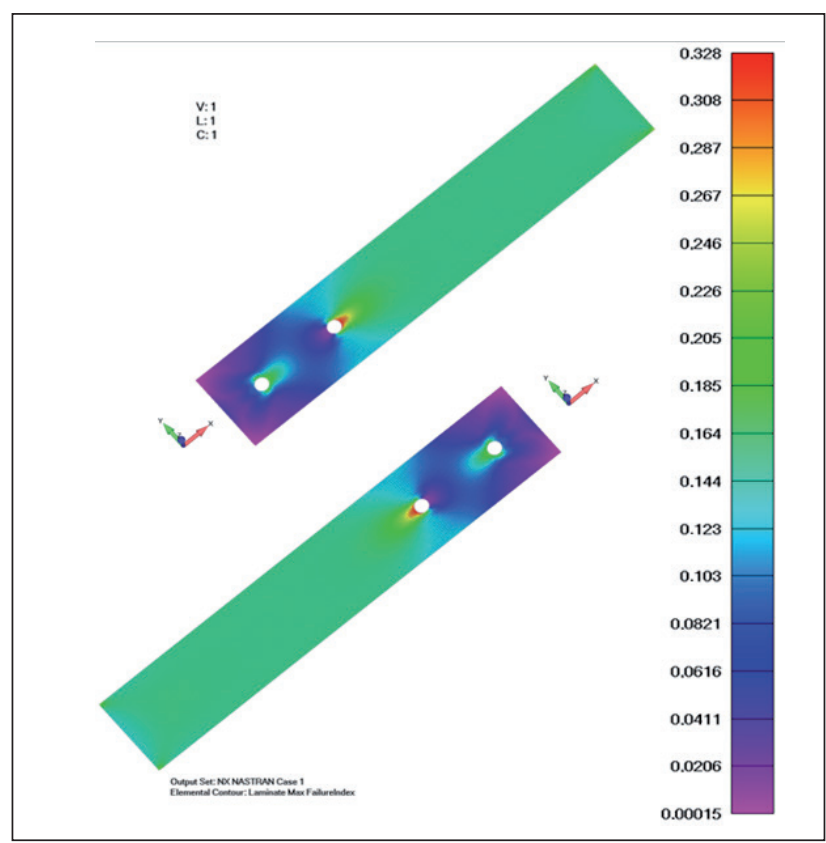

Figure 10: Fail index, boundary condition 1: geometry 1, baseline (according to ASTM D5961 - procedure B) (admensional). 
affect in displacement more significantly if the edge were loose, condition that does not represent the tension machine in real condition test.

It is important to point that, due to its complexity, there are several failure modes verification methods for laminate reinforced composite materials ${ }^{2}$. Venturini ${ }^{2}$ mentions the existence of more than 70 references for damage and failure criteria. Therefore, the simulations made contribute to the hypothesis that the parallelism tolerance could be wider, but does not complete the studies.

Additionally, it is well known that none of the actual Finite Elements Analysis software can simulate such an accurate condition as one representative test joints batch due to the wide variants number and possible errors sum that accumulates since the joint preliminary conception until the test results interpretation.

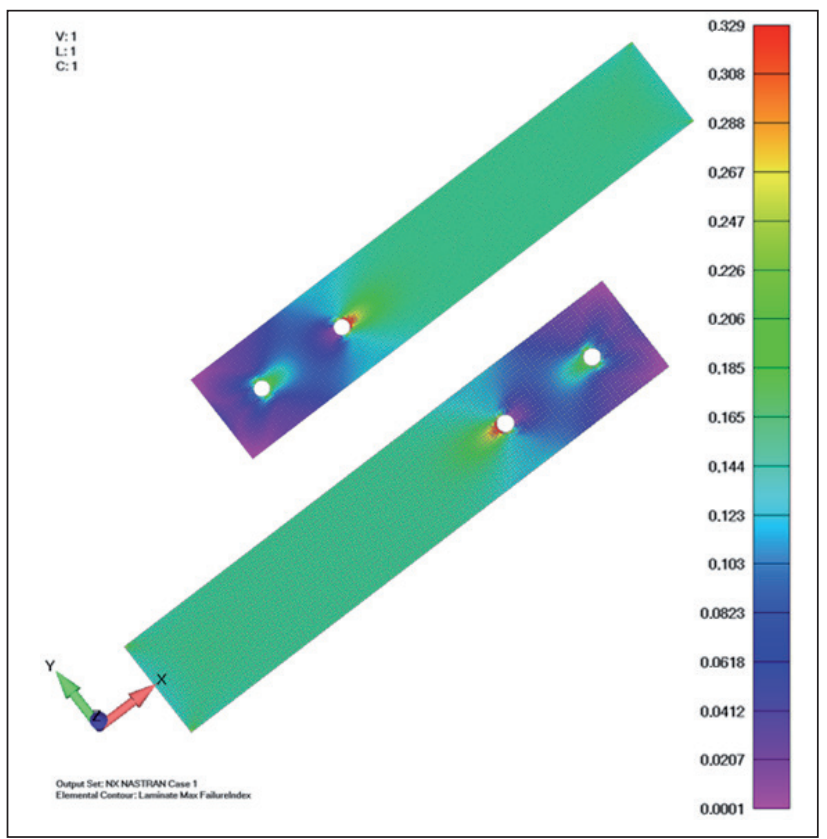

Figure 11: Fail index, boundary condition 1, geometry 2, with parallelism error (admensional).

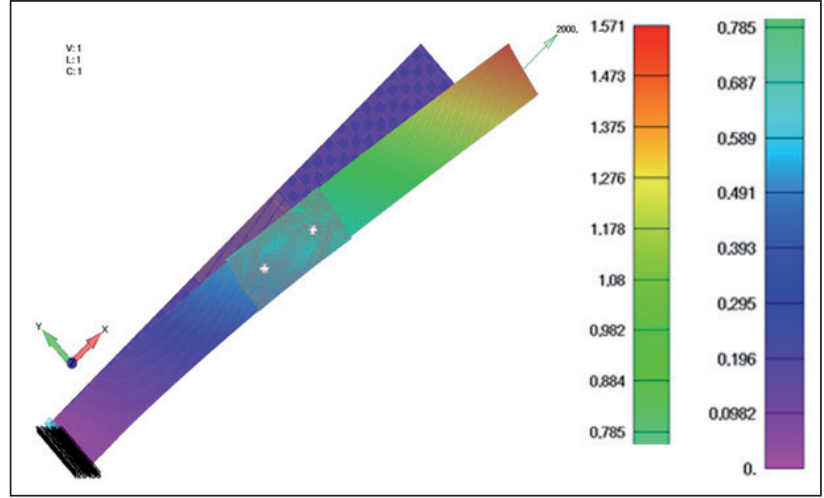

Figure 13: Displacement results (in $\mathrm{mm}$ ) in Geometry 2, boundary condition 2.

At last, it was not found at standard ASTM D5961 ${ }^{6}$ explanations or justifications about the parallelism tolerance required, as well as in the materials indicated in the literature, other parameters were more emphasized as determinants for the tests performance than a parallelism error in a centesimal of millimeters range. Among this parameters, it was mentioned hole/fastener clearance, fastener torque and material, fastener head type and size, pitch, fiber/matrix interface, laminate stiffness and thickness ${ }^{3}$, lay-up and material orthotropy, shim's thickness, moisture and temperature conditions and, more importantly, edge distance and ratio fastener diameter to laminate thickness ${ }^{2}$.

\section{CONCLUSION}

Based on the literature and the simulations made using Nastran@ software, it was observed that there are several variables that can influence the composite joints performance in bearing tests that are more critical than a parallelism error up to $1 \mathrm{~mm}$.

However, even that Procedure B tolerances requirements ${ }^{6}$ increase manufacturing costs, a variable is possible to be obtained, among other related to composite joints manufacturing and tests that are harder to control. One possible manufacturing method

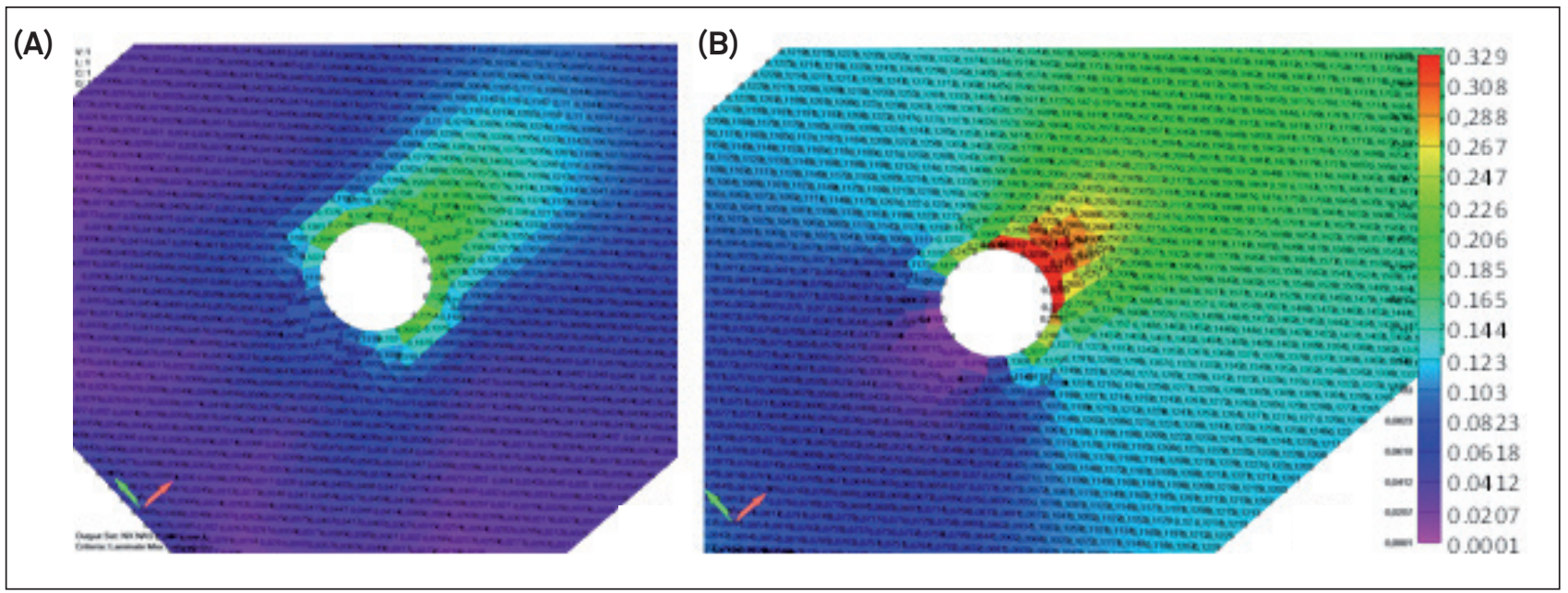

Figure 12: Close of the fail index in geometry 2, boundary conditions 1 specimen, right half: (A) Hole 1; (B) Hole 2. 
would be to drill the composite joint together with a tooling that would use datum $A$ as reference, and then one additional setup of contour grinding.

Therefore, it was concluded that the pointed error of parallelism would not affect the bearing primary failure mode, but it could affect input data results precision, as applied force, stress and strain, which could be critical depending on the accuracy necessary for the test, possibly leading to higher safety factor application.

It is important to highlight that this study does not close all the necessary analysis to conclude how much the parallelism tolerance could influence the test performance. There is a complexity inherent to composite materials, innumerous methods to predict this material behavior, and several variables that must be controlled during the test specimens manufacturing and test to evaluate singly the parallelism effect on composite joint performance.

\section{AKNOWLEDGMENTS}

We would like to thank our dear teachers, FATEC São José dos Campos office team and engineers Renata G. Guerra and Viviane J. S. Prado. Thanks to FAPESP for the congress support (process number: 2017/13959-5).

\section{REFERENCES}

1. Marchezin E, Pardini LC, Guimarães VA. Avaliação do comportamento em fadiga de juntas estruturais de ligas de Al2024T3 coladas com adesivo epóxi. Matéria (Rio de Janeiro). 2012;17(1):889-900. http://dx.doi.org/10.1590/S151770762012000100002

2. Venturini Neto S. Estudo de junções aeronáuticas híbridas (metalcompósito) unidas mecanicamente [Master's thesis]. São Carlos: Universidade de São Paulo; 2010.
3. Hart-Smith LJ. Joints. In: Reinhart TJ, editor. Engineered materials handbook: composites. Michigan: ASM International Handbook 1987.

4. Niu Chun-Yung M. Airframe structural design. California: Commits Press; 1988

5. Anderson TL. Fracture mechanics: fundamentals and applications. 2 ed. Nova York: CRC Press; 1995.

6. American Society for the Testing and Materials. Standard test method for bearing response of polymer matrix composite laminates. ASTM D5961. West Conshohocken: ASTM International. [Cited 2016 May 16]. Available from: https://www. astm.org/Standards/D5961.htm

7. Gramoll K. Mechanics theory - Bearing Stress [internet]. [Cited 2016 Oct. 6]. Available from: http://www.ecourses.ou.edu/cgibin/eBook.cgi?topic $=$ me\&chap_sec $=01.2 \&$ page $=$ theory

8. United States. Composite materials handbook - polymer matrix composites: materials usage, design and analysis. Washington: U.S. Dept. of Defense; 2002.

9. United States. Composite materials handbook - polymer matrix composites: guidelines for characterization of structural materials. Washington: U.S. Dept. of Defense; 2012.

10. Levy Neto F, Pardini LC. Compósitos Estruturais. São Paulo: Editora Blucher; 2006.

11. Swanson SR, Qian Y. Multiaxial characterization of T800/39002 carbon/epoxy composites. Composites Science and Technology. 1992;43(2):197:203. https://doi.org/10.1016/02663538(92)90009-R

12. Bheemreddy $V$, Jensen A. Composite laminate modeling [internet]. Portland: Predictive Engineering. [Cited 2017 Aug. 20]. Available from: http://appliedcax.com/support-and-training/ technical-online-seminars/seminars/composite-laminatemodeling/Composite\%20Modeling\%20White\%20Paper\%20 2014\%20Rev-0.pdf

13. Niu MC. Airframe stress analysis and sizing. 2 ed. Hong Kong Hong Kong Conmilit Press LTD; 1999. 